\begin{tabular}{cccc} 
E & S & J & E \\
\hline & & $\begin{array}{c}\text { ROCZNIKI NAUK SPOEECZNYCH } \\
\text { Tom 13(49), numer 3 }-2021 \\
\text { DOI: https://doi.org/10.18290/rns21493.6 }\end{array}$ &
\end{tabular}

MAREK JAN CHODAKIEWICZ

\title{
BIBLIOGRAFIA ISLAMU
}

Pytano mnie kilkakrotnie, po moich wystąpieniach i felietonach, o ich podstawy historiograficzne, a jeszcze częściej proszono o rekomendacje bibliograficzne. Co czytać? To zależy od potrzeb czytelnika. Profesjonalnemu badaczowi problematyki doradzam skonfrontowanie swej listy bibliograficznej prac z moją w celu jej uzupełnienia, albo stwierdzenia jej adekwatności. Studentowi przedmiotu na poziomie zaawansowanym sugeruje przeczytanie nie tylko tego, czego jeszcze nie zna, ale ponowne przejrzenie pozycji, z którymi już się zaznajomił. Studentowi, który stawia pierwsze kroki na mahometańskim polu, podpowiadam, że warto przebrnąć przez wszystkie pozycje, które wymieniam w niniejszym eseju bibliograficznym i w przypisach. Do wybrania części tytułów omawianych poniżej chciałbym zachęcić amatora, a nawet takiego przeciętnego człowieka, który chciałby wiedzieć, co, gdzie, kto, skąd i dlaczego dzieje się jak się dzieje wśród muzułmanów oraz w ramach ich oddziaływania na resztę ludzkości.

Każdy - od profesjonalisty do amatora - musi najpierw nauczyć się języka angielskiego, aby wejść w światy islamu. Większość prac naukowych i popularnych o mahometanizmie i jego wyznawcach jest pisana w tym właśnie języku. To samo dotyczy konferencji naukowych i rozmaitych wykładów na uczelniach i w sieci. Ci, którzy chcą poświęcić swe życie badaniom tych zagadnień, będą musieli posiąść arabski, farsi, paszto, dari, urdu i kilkadziesiąt innych języków, na przykład berberski czy wolof, o ile ich pasja zagna ich do północno-zachodniej Afryki. Ale angielski jest podstawą.

Prof. dr MAREK JAN CHODAKIEWICZ - polonijny historyk amerykański, profesor w The Institute of World Politics w Waszyngtonie, od 2008 roku kieruje Katedrą Studiów Polskich im. Tadeusza Kościuszki (The Kosciuszko Chair of Polish Studies), specjalizujący się w badaniu stosunków polsko-żydowskich, tematyki Szoa oraz historii Europy Środkowej i Wschodniej XIX i XX wieku; adres do korespondencji: e-mail: mchodakiewicz@iwp.edu. 
Główną amplifikacją angielskiego jest fakt, że Stany Zjednoczone są najpotężniejszym imperium w historii świata. Pax Americana dyktuje konieczność znajomości angielskiego z powodów praktycznych: gospodarczych, politycznych i militarnych. Oczywiście dotyczy to również nauki, bowiem amerykańskie uczelnie wyższe, a szczególnie Harvard, Yale, Columbia, Princeton, Berkeley, Stanford czy University of Chicago, w dużym stopniu przyćmiły europejskie - Oxford, Cambridge czy Uniwersytet Paryski. Angielski jest językiem panującym na wszelkich poziomach: od pop-kultury do kultury Parnasu; od humanistyki do technologii.

Moja propozycja bibliograficzna to zupełne minimum, z którym powinien się zapoznać każdy człowiek złakniony wiedzy o islamie. Większość omawianych tytułów to pozycje anglojęzyczne, przede wszystkim dlatego, że angielski to lingua franca dnia dzisiejszego. W obiegu naukowym spełnia funkcję podobną do tego, jaką łacina pełniła w średniowieczu. Jednak angielski jest na dodatek globalny i jego potęga amplifikowana jest wielokrotnie mocniej na skalę masową, o jakiej nie mogła przecież marzyć łacina. Ponadto angielski jest językiem byłych brytyjskich kolonizatorów. Ich intelektualiści wielokrotnie byli pionierami nauki o światach islamu. W imperium, w którym nigdy nie zachodziło słońce, zamieszkiwały przecież miliony muzułmanów, od Egiptu do Indii. Potem to właśnie oni - oraz inne potęgi kolonialne - ściągnęły tłumy mahometan do Europy. I to również znalazło swoje odzwierciedlenie w nauce i piśmiennictwie po angielsku.

Francuski od dawna nie ma tej samej potęgi i tej samej rangi, co angielski. Dotyczy to również studiów nad islamem. Jednak frankofońscy naukowcy są nierzadko wielkimi znawcami tematu, chociaż ograniczającymi się głównie do byłych terenów kolonialnych Francji ${ }^{1}$. To samo ma się z innymi byłymi kolonialistami. Jawią się przede wszystkim jako specjaliści regionalni. Co więcej, zachodni naukowcy innych nacji - głównie spadkobiercy imperiów kolonialnych, tacy jak Francuzi, Holendrzy, Włosi, a nawet Niemcy - również mają tendencję do tłumaczenia swych prac na angielski albo wręcz pisania w tym języku².

Odnosi się to także do samych muzułmanów: przyjeżdżają oni do zachodnich uniwersytetów, zdobywają stypendia i piszą o sobie bardzo często - jeśli nie głównie - po angielsku i w ramach metodologicznych zachodnich. To samo dotyczy też spadkobierców mahometan zamieszkałych i zasymilowanych na

\footnotetext{
${ }^{1}$ Naturalnie są też wyjątki, choćby znakomita praca historyczno-geopolityczna mojego znajomego z St. Cyr, Oliviera Hanne'a (zob. Hanne, 2017).

${ }^{2}$ Zob. np. wyśmienitą monografię francuskiego naukowca, Oliviera Roya (1990), albo wielce wnikliwą pracę niemieckiego badacza, Romana Loimeiera (2013).
} 
Zachodzie. Trend ten naturalnie zaczął się jeszcze przed 1914 roku i nasilał się stopniowo w okresie po II wojnie światowej. Obecnie osiągnął bardzo wysoki poziom szczególnie dzięki stypendiom i grantom dla zachodnich uczelni i innych ośrodków naukowych, szczodrze płynącym z Arabii Saudyjskiej i innych bogatych w zasoby energetyczne krajów zatoki perskiej. Warto podkreślić, jak ważne jest nauczenie się przekazywania swoich odkryć, interpretacji i racji w języku angielskim, ale równie istotne jest posługiwanie się zachodnią retoryką i metodologią w ramach anglosaskiego kontekstu kulturowego ${ }^{3}$.

Wyjątkiem od tej reguły angielszczyzny jest oczywiście rosyjskie imperium kolonialne postsowieckie. Od XIX wieku rosyjskojęzyczni znawcy islamu, Azji Środkowej, orientaliści głównie, ograniczają się do aktywności naukowej we własnej mowie. Odnosi się to szczególnie do okresu sowieckiego. Tłumaczenia były wtedy raczej wyjątkami. Dotyczyły one właściwie pojedynczych białych emigrantów, dużo rzadziej zaś sowieckich specjalistów, spętanych cenzurą i metodologią dialektyki marksizmu-leninizmu. Obecnie jednak następuje powolny proces integracji nauki rosyjskiej, także w odniesieniu do tematów uprzednio uznawanych za egzotyczne, takich jak islam, do głównego nurtu nauki światowej. Oczywiście po angielsku.

Ten proces rodzi się na minimalnym poziomie również $w$ innych państwach postsowieckich, zwłaszcza tych zamożniejszych, choćby w Azerbejdżanie czy Kazachstanie, ale także np. w Polsce. Napędzenie tego procesu i nagłośnienie osiągnięć naukowych - chociażby polskich archeologów - na poziomach ezoterycznym i popularnym zależy od stopnia samouświadomienia o wartości takich osiągnięć, pozbycia się kompleksów, kontaktów w świecie zachodnim oraz funduszy. Najpilniejsze są publikacje monograficzne, aby odnotowano obecność polskiej nauki. I musi być to oczywiście po angielsku .

\footnotetext{
${ }^{3}$ Zob. np. dzieło irańskiego naukowca, rozpoczęte pod przewodnictwem jego zachodnich mentorów, którego autorem jest Seyyed Hossein Nasr (1978).

${ }^{4}$ Świadomie pomijam w Bibliografii naukowe prace polskojęzyczne dotyczące islamu, a szczególnie polityczno poprawne kalki zachodnich enuncjacji tolerancjonizmu. Każdy w kraju ma do nich dostęp i może z nimi łatwo się zapoznać - odwrotnie niż z tekstami obcojęzycznymi, na których opieramy nasze światy islamu. Nie znaczy to, że obecnie nie ma ciekawych prac akademickich, zob. np.: Jerzy Zdanowski, Państwo na muzutmańskim Bliskim Wschodzie. Procesy genezy i czynniki trwania (Kraków: Krakowska Akademia im. Andrzeja Frycza Modrzewskiego, 2014), https://repoz ytorium.ka.edu.pl/bitstream/handle/11315/6916/Zdanowski-Panstwo.pdf?sequence=1\&isAllowed=y. Wymienimy tutaj jednak kilka krytycznych pozycji polskojęzycznych, aby ukierunkować zainteresowanych tą tematyką. Dobrym przykładem komparatystyki kulturowej jest praca Feliksa Konecznego pt. O wielości cywilizacyj (Kraków: Gebethner i Wolff, 1935), po 1989 roku wydana m.in. przez Antyk w Polsce, a na emigracji przetłumaczona przez Jędrzeja Giertycha na angielski jako On the Plurality of Civilizations (London: Polonica Publications, 1962). Szkopuł w tym, że zawarta w niej dyskusja dotycząca islamu jest nieadekwatna do obecnych potrzeb. Koneczny koncentruje
} 
Co czytać? Wybieram pozycje raczej arbitralnie i subiektywnie, mając nadzieję, że zachęcą one czytelnika do dalszego czytania. Kolejne tytuły zamieszczam w bibliografii. Proponuję wybrane źródła pierwotne (primary sources), niektóre prace encyklopedyczne, periodyki oraz nieliczne monografie i prace popularyzatorskie.

Ze źródeł oryginalnych czytamy przede wszystkim Koran, najlepiej tłumaczenie z $1997 \mathrm{roku}^{5}$. To jest konieczne dla niewiernych, aby zrozumieć słowa i przekaz w języku słynnym ze swojej racjonalności, precyzyjności i logiki. Trzeba znać arabski, aby upajać się rytmem poetyckiej recytacji świętej księgi bez zwracania uwagi na brak logocentryzmu. Koran nie jest chronologiczny, a ułożony zwrotkami - od najdłuższej do najkrótszej.

Bezcenna jest też pierwsza biografia islamskiego proroka Mahometa (zob. Ibn Isḥāq, 1955). Spisano ją prawie sto lat po jego śmierci, z pozycji prymatu wyznawców w Medynie, tzw. Pomocników; szczególnie promuje optykę świeżych konwertytów, wywodzących się z wziętych do niewoli perskich zoroastrian, jakimi była rodzina autora. Najcenniejszym aspektem tej biografii jest zasięganie opinii naocznych świadków, a także ich rodzin, jak również częściowa weryfikacja chronologii Koranu. Dopełnia tę biografię bodaj pierwsza solidna historia powstawania pierwszego kalifatu islamskiego. Spisał ją w IX wieku piewca dynastii Abbasydów, perski dziejopis - Al-Baladhuri (1916).

swoją krytykę głównie na sprawach dyskryminacji kobiet, szczególnie wielożeństwa. Dużo bardziej pogłębiona jest: Abd Oul-Masih’ Al Ghalwira, Geneza islamu i osoba Mahometa, cz. 1 i 2, thum. Marcin Dybowski (Komorów: Wydawnictwo Antyk Marcin Dybowski, 2012). Napisana pod pseudonimem, zapewne Polaka, być może osoby duchownej, który - jak się wydaje - jest wybitnym specjalistą od teologii mahometańskiej i wczesnej historii tej wiary, znawcą arabskiego i źródeł w tym języku. W wyważony i profesjonalny sposób o mahometanizmie opowiada dwojgu włoskim dziennikarzom, Giorgio Paolucciemu i Camille Eidowi, arabski jezuita, Samir Khalil Samir (Islam. Sto pytań, tłum. Karol Klauza, Warszawa: Instytut Wydawniczy PAX, 2004). O dżihadystach w ostatnich 200 latach intrygująco wykłada Jerzy Rohoziński (Narodziny globalnego dżihadu, Poznań: Wydawnictwo Poznańskie, 2017), a szczególnie cenna dla badaczy polskich jest zamieszczona w tej pracy obszerna bibliografia. Bez pardonu rozprawia się z wyzwaniami dnia dzisiejszego w kontekście chwiejącej się cywilizacji zachodniej i rozpychającego się mahometanizmu Paweł Lisicki w pracach Dżihad i samozagłada Zachodu (Lublin: Fabryka Snów, 2015) oraz Poza polityczna poprawnością: Polska, Europa i Kościót między nihilizmem a islamem (Kraków: Wydawnictwo M, 2017). Ciekawy jest też zbiór publicystyki, szkoda, że bez syntetycznego wprowadzenia, na temat postępującej islamizacji Francji - zob. Bogdan Dobosz, Emiraty francuskie (Warszawa: Biblioteka Wolności, 2016). Z tłumaczeń na polski warto zapoznać się z: Jean [M.] Alcader, Prawdziwe oblicze islamu (Komorów: Wydawnictwo Antyk Marcin Dybowski, 2011). Wśród literackich głosów polskich o islamie wybija się (oby nie proroczy) Kazimierz Braun, Dzwon na trwogę (Warszawa: Oficyna Wydawnicza Volumen, 2016).

${ }^{5}$ Do wydania z 1997 roku odnoszę się w niniejszej pracy. 
Z literatury arabskiej u jej szczytu polecam słynne Opowieści z tysiaca i jednej nocy. Fascynująca, barwna opowieść dziewczyny, która musi rozbawić swego prześladowcę swymi opowieściami, albo zginąć z jego ręki. Ostrzegam, opowiadania są pełne stereotypów, na przykład o nadpobudliwym seksualnie czarnym afrykańskim niewolniku, który zwisa z drzew jak małpa w ogrodzie, a potem obsługuje nadobną muzułmankę. Królewskie zabójstwa niewiernych małżonek cudzołożących z czarnymi rabami bledną przy sułtańskim zwyczaju żenienia się co dzień $\mathrm{z}$ inną dziewicą, rozprawiczaniu jej, a potem rano obcinaniu jej głowy, aby nigdy nie miała okazji do zdrady małżeńskiej.

$\mathrm{Z}$ wielu intelektualnych propozycji islamskich warto zapoznać się minimum z dwoma z okresu średniowiecza: dziełem Ibn Khaldūna, który zapoznaje nas $\mathrm{z}$ fascynującą teorią cykli powstawania, gnicia i upadku cywilizacji ${ }^{7}$, oraz z pracą Shihaba Al-Din Al-Nuwayriego (2016), co jest swoistym almanachem sumy szczytowej wiedzy muzułmańskiej elity na średniowiecznym Bliskim Wschodzie.

Jeśli chodzi o wspomnienia podróżników, najbardziej fascynujące są przygody właściwie w większości światów islamu, które przeżył Ibn Battutah $\left(2003^{8}\right)$, a następnie opis Indii Alberuniego'. Wyprawy muzułmańskich i żydowskich

${ }^{6}$ The Arabian Nights (2004). Jest to błyskotliwe tłumaczenie (z efektownie uzupełniającymi tekst przypisami) pióra słynnego podróżnika, oficera kawalerii i wiktoriańskiego szpiega brytyjskiego - Richarda Sir Burtona. Był on pierwszym białym człowiekiem, który w przebraniu wkradł się do Mekki. Jako pierwszy spenetrował Somalię. Dostał się do wnętrza Afryki. Podróżował właściwie po całym świecie. Znał ponad 40 języków; stał się koneserem kultur tubylczych i dlatego jego koledzy nazywali go z dezaprobatą „,biały czarnuch” (,white nigger”, s. 87); popierał poligamię (s. 118-119). Był agnostykiem, który m.in. usiłował uwieść katolicką zakonnicę na Goa; aż w końcu ożenił się z katolicką Angielką. Uważał, że kobiety muzułmańskie mają wysoki status prawny (,The legal status of womankind in Al-Islam is exceptionally high, a fact to which Europe has often been assured, although the truth has not yet even penetrated into the popular brain", s. 182). Zob. Burton (1993).

${ }^{7}$ Ibn Khaldūn (1967) opisuje „,asabiyya” jako „solidarność grupową” (co Franz Rosenthal tłumaczy jako „group feeling” - „zbiorowe uczucie”) i identyfikuje ją jako najważniejszy czynnik kształtujący stosunki między koczownikami (Arabami i Berberami) a ludźmi cywilizowanymi. Jest ona najbardziej rozwinięta wśród barbarii. Natężenie jej siły decyduje o powstawaniu dynastii i państw, głównie przez podbój, ale również przez zastępowanie starych władców przez nowych barbarzyńców. Osłabienie solidarności grupowej - głównie z powodu porzucenia koczowniczych przyzwyczajeń na rzecz miejskiego luksusu - jest powodem cyklicznego upadku dynastii i państw. Poważny student powinien zapoznać się z wersją, która zawiera m.in. pełniejszą dyskusję na temat dżihadu - zob. Ibn Khaldūn (1958). Uczony ten stale fascynuje, a odnosił się do niego z podziwem Arnold J. Toynbee, jak również wielu innych. Najnowsze prace o nim zob. Alatas (2013), Dale (2015), Irwin (2018).

${ }^{8}$ Nie jest to tłumaczenie stricte naukowe. Najlepszą pracę o tym fascynującym podróżniku napisał Dunn (1986).

${ }^{9}$ Alberuni (2002). Jest to przedruk bez redakcji (a więc z wieloma chochlikami drukarskimi) dzieła tłumaczonego pod koniec XIX wieku. 
dyplomatów, kupców czy podróżników (np. Ibrahima Ibn Jakuba) do wschodnich Słowian, Wikingów i ludów tureckich, wzdłuż rzeki Wołgi i dalszych, północnych i zachodnich okolic, w X wieku, jak również w innych czasach są ciekawie oddane w pracy opartej głównie na raporcie arabskiego dyplomaty, Ibn Fadlāna (2012).

Z okresu krucjat warto poznać niezwykle ciekawe wspomnienia i refleksje ich mahometańskiego uczestnika w XII wieku, Usamy Ibn Munqidha (zob. Munqidh, 2008). Z późniejszych źródeł wręcz przeraźliwy jest najlepszy i najpełniejszy przykład antychrześcijańskiego dżihadu z XVI wieku przeciw Etiopii. Z kroniki tej wylewa się fanatyzm, opisy masowych mordów, zniewalania, rabunków, desakracji kościołów i upartych, wieloletnich ofensyw przeciwko abisyńskiemu cesarstwu, które stanęło na krawędzi eksterminacji i tylko cudem potrafiło się uratować (Šihāb ad-Dīn Aḥmad bin Àbd al-Qāder bin Sālem bin Ùtmān ['Arab Faqih], 2003 ${ }^{10}$ ). Kontrastem są nieco późniejsze refleksje muzułmańskich podróżników po chrześcijańskim Zachodzie w XVII wieku (In the Lands of the Christians, $2003^{11}$ ).

Jeśli chodzi o opisy światów islamu przez Europejczyków, z całej masy intrygujących pozycji należy przeczytać przynajmniej cztery: dzieje spisane przez Wilhelma z Tyru, arcybiskupa i krzyżowca z końca XII wieku (William

\footnotetext{
10 ‘Arab Faqih jest autorem tej ponurej opowieści, którą można nazwać lakoniczną kroniką zabijania i zniewalania chrześcijan, rutynowych masakr wojów i cywilów. Czytamy o zmuszaniu tych, co przeżyli, do przechodzenia na islam, gwałceniu ich żon, matek i córek, a także o rabowaniu, profanowaniu, oraz paleniu ich kościołów. Na temat tej ostatniej czynności autor daje około 30 przykładów, które opisuje bardziej szczegółowo (s. 32, 36, 60, 138, 144, 161, 163, 165-167, 184-185, 190-192, 222, 227, 239, 247-251, 265, 272, 304, 312, 346-347). Smutne, ale większość jeńców popełniała apostazję, tak jak większość podbitej ludności dostosowywała się do okupanta. Chrześcijańscy żołnierze poddawali się całymi oddziałami, czasami wydając swoich dowódców, aby uniknąć śmierci z bezlitosnych rąk muzułmańskich. Od czasu do czasu starali się uciec, ale wtedy mogli się spodziewać rzezi, gdy ich złapano. Odnotowuje się wiele przykładów męczennictwa, ale większość męczenników nie miała wyboru. Tylko niektórzy mieli, ale świadomie wybrali śmierć, a nie wyrzeczenie się swej chrześcijańskiej wiary. Według muzułmańskiej interpretacji tej katastrofy: Imam „Ahmed [Leworęczny] rządził Abisynią i przyniósł jej pokój” (“[Imam] Ahmed [the Left-Handed] ruled the country of Abyssynia and brought it peace” (s. 20). Po arabsku „pokój”, czyli poddanie się, to właśnie islam. Autor podaje te wszystkie horrory jako sprawę normalną. Widzi katastrofę jako zarządzoną przez Allaha. Prawie się udało. Dżihadyści doprowadzili chrześcijańską Etiopię na skraj eksterminacji. Zabili nawet cesarza i większość arystokratów. Tylko wspólna etiopsko-portugalska krucjata (o której 'Arab Faqih milczy w niniejszej kronice) ocaliła trzecie najstarsze chrześcijańskie królestwo na ziemi. Chrześcijanie się zjednoczyli i pokonali dżihad. Notabene, ciekawa jest informacja, że żydowscy Falasze przyłączyli się do muzułmanów przeciw chrześcijanom w ostatniej fazie podboju (s. 378-379).

${ }^{11}$ Tłumacz i redaktor, Nabil Matar, jest apologetą islamu i antyoksydentalistą. Jednym z najcenniejszych wątków tej pracy jest pokazanie, jak bardzo ówczesna mahometańska krytyka łacińskiego chrześcijaństwa polegała na intelektualnych konstruktach protestanckich.
} 
of Tyre, 1943); opowieści brytyjskiego szpiega w Mekce i Medynie oraz w Zanzibarze i Somalii z XIX wieku, kapitana Richarda Francisa Burtona (Burton, 1964, 1856); wspomnienia brytyjskiego dyplomaty, Wilfreda Thesigera, z Półwyspu Arabskiego i Iraku z połowy XX wieku (Thesiger, 2012 - książka traktuje o koczowniczych Beduinach w Omanie i Arabii Saudyjskiej; Thesiger, 2008 - opowiada o ludności zamieszkującej tereny bagienne obecnego Iraku). Podobne w nastroju są wspomnienia Bertrama Thomasa (1932), Gertrude Bell (2015) oraz Thomasa Edwarda Lawrence'a (1999).

Dostępne są też niezliczone inne źródła opublikowane po angielsku. To samo dotyczy prac naukowych. Zasygnalizujmy niektóre z nich. Nie sposób bowiem omówić wszystkie, ale warto przynajmniej wskazać na trendy w nauce o światach islamu. Trendy - zgodnie z duchem czasu - zwykle są liberalne i lewicowe. Ale nie zawsze tak było.

Naukę należy zacząć od zapoznania się z dorobkiem wczesnych specjalistów od mahometanizmu. The Encyclopaedia of Islam (1913-1938) jest podstawą, a dwa następne jej wydania - jej dopełnieniem. Można też konsultować The Encyclopedia of the Qur'ān (2006), pamiętając, że to produkt współczesności. Encyclopedia Britannica, najlepiej wydanie 11, nie skażone polityczną poprawnością, pisane przepiękną prozą (1910-1911) pod opieką Cambridge University, to generalna podstawa. Bardzo przydatna sekcja o islamie i jego światach - szczególnie jako odtrutka na postnowoczesne wywody. Z podobnych względów preferuję The Cambridge History of Islam (1970) w dwóch tomach, bardziej niż The New Cambridge History of Islam (2010) w sześciu tomach. Ta pierwsza pozycja jest faktograficzna raczej niż analityczna ${ }^{12}$. Chociaż druga jest na pewno pełniejszym ujęciem zjawiska, jednak niestety jest też naznaczona ambiwalentnym i relatywistycznym duchem czasów tzw. postnowoczesności.

Jeśli chodzi o podręczniki i monografie wprowadzające w światy mahometańskie, to jest ich bardzo wiele. Propozycje zawężam arbitralnie do kilkudziesięciu znaczących pozycji o rozmaitej orientacji i wartości naukowej.

Praca Karen Armstrong (2010) to synkretyczny i politycznie poprawny pean na cześć religii muzułmańskiej. Autorka, była zakonnica katolicka, wychwala egalitaryzm islamu i jest pełna podziwu dla jego Proroka z powodu bardzo dobrego traktowania kobiet przez niego. Ktokolwiek się z nią nie zgadza, jest naturalnie nietolerancyjnym faszystą. Tamim Ansary (2010) przedsięwziął niezwykle wyrafinowany zabieg propagandowy, ukryty pod maską dziejopisarstwa. Ten długoletni rezydent Stanów Zjednoczonych wywodzący

\footnotetext{
12 Jej drugie wydanie z 1977 roku.
} 
się z Afganistanu, używając amerykańskiej wyobraźni, symbolu i idiomu, w rozrywkowy i przystępny sposób przekonuje o świetności i wyższości cywilizacji islamu nad wszelkimi innymi.

Przebija go John L. Esposito $(1999,2011)$ z wyżyn swojej pozycji profesorskiej w Georgetown University. Wyprodukował on wybitnie promahometański podręcznik wskazujący, że ów liberalny katolicki uczony albo doświadcza samopoturczenia, albo jest agentem wpływu islamu. Po apologetycznym wstępie szeroko malującym historię tej cywilizacji, autor koncentruje się w dużym stopniu na współczesnej problematyce mahometanizmu na całym świecie, islam jest oczywiście religią pokoju. W podobnym tonie jest utrzymany, zredagowany także przez niego, tom głosów naukowych życzliwych islamowi.

Marshall G.S. Hodgson, liberalny protestant zakochany w światach islamu, stworzył monumentalne dzieło, zredagowane i wydane pośmiertnie (Hodgson, 1977). Jest to przede wszystkim historia intelektualna, wręcz literacko-teologiczna, chociaż inne aspekty dziejów islamu - ekonomiczne, polityczne, społeczne i wojskowe - również są do pewnego stopnia naświetlone. Praca jest pełna aluzji i zaskakujących, nie tylko literackich odkryć. To trudne, bardzo wymagające dzieło, miejscami niemal mistyczne, ale kluczowe do rozwikłania bardziej ezoterycznych aspektów cywilizacji islamskiej, w tym poezji sufickiej czy kultury dworskiej ${ }^{13}$.

Ira M. Lapidus (2002) wyprodukowal, w formie masywnego tomu, podręcznik. Tej całkiem użytecznej pomocy dydaktycznej brakuje jednoznacznego leitmotiv. Choć pisana bez wielkiej wyobraźni i polotu, przez pracę przebiega teza, że mahometanizm ma różne oblicza w zależności od położenia geograficznego, ale w obecnym globalnym świecie niektóre islamskie siły dążą do ustanowienia muzułmańskiego uniwersalizmu, który opiera się na przywróceniu surowych norm z czasów Proroka. I w końcu z generalnych prac polecam The Sword of the Prophet (Trifkovic, 2002). Serge Trifkovic to paleokonserwatywny Serb, niekryjący swojej nienawiści do mahometanizmu i z pasją obnażający wszelkie jego zbrodnie, ohydztwa i dziwactwa, szczególnie w stosunku do prawosławnych. Praca raczej powierzchowna, ale przydatna jako korektorska kropla w morzu politycznej poprawności proislamskiej.

Jeśli chodzi o naukowe monografie poszczególnych aspektów zjawiska mahometanizmu dla zaawansowanych, najbardziej zorganizowaną i najlepiej

\footnotetext{
${ }^{13} \mathrm{Na}$ marginesie, autorowi - odwrotnie niż wielożeństwo - nie podobały się krucjaty. O kulturze dworskiej zob. też Naaman (2016). Pers Ibn Abbad (938-995) służył jako wezyr dynastii Buidów pod koniec $\mathrm{X}$ wieku $\mathrm{O} a d a b$ w znaczeniu prawa zwyczajowego administrowanego przez dwór zob. Metcalf (1984).
} 
naświetlającą problematykę pluralizmu islamskiego i rozmnażania się sekciarskiego przez pączkowanie w okresie pierwszego milenium istnienia tej religii jest praca Jonathana P. Berkeya (zob. Berkey, 2002). Intelektualnym dynamitem o początkach islamu jest książka, którą napisali Patricia Crone oraz Michael Cook (Crone, Cook, 1977). Autorzy przedstawiają alternatywną interpretację powstania i transformacji mahometanizmu z judaistycznej i chrześcijańskiej herezji w odrębną, samodzielną religię allahową ${ }^{14}$.

Wciąż funkcjonalne jest klasyczne studium wprowadzające do zagadnień teologicznych i prawnych muzułmańskich, napisane przez Ignaza Goldzihera, jednego z pionierów nauki o mahometanizmie na Zachodzie. Ujmuje on te kwestie z punktu widzenia sunickiego, bardzo wrogiego szyizmowi. Wyraża sceptycyzm wobec źródeł kanonicznych islamu (Goldziher, 1917, 1966, 1981) ${ }^{15}$. Jego wiernym kontynuatorem był Joseph Schacht, wielki znawca prawa islamskiego (Schacht, 1966, 1983) ${ }^{16}$. Najnowszą korektę ich podejścia z perspektywy szkoły prawnej Maliki dał nam Yasin Dutton, który broni solidności tych źródeł (Dutton, 2002) ${ }^{17}$. Wnikliwa analiza chronologicznie wybranych

\footnotetext{
${ }^{14}$ Będziemy się odnosić do tej monografii wielokrotnie w naszej pracy, szczególnie opisując alternatywne dzieje początków mahometanizmu.

${ }^{15}$ Ignaz Goldziher to węgierski uczony, założyciel nowoczesnych studiów islamskich w Imperium Habsburskim. Uczęszczał na słynną uczelnię mahometańską w Kairze, Al-Azhar, mimo że był żydowskiego pochodzenia (Icek Jehuda Goldziher). Nie tylko był wielkim orędownikiem islamu typu sunickiego, lecz także z uporem wyszukiwał w nim elementy tolerancji. Jednym słowem jego prace są nacechowane ideologią liberalną, której hołdował. Mimo to jego publikacje pozostają wciąż wartościowe. Również dlatego, że Goldziher stosował logocentrykę i odnosił się sceptycznie do wielu źródeł mahometańskiej religii, a szczególnie do hadisów. Apologetycznie i dezinformacyjnie o Al-Azhar zob. w: Nakissa (2019).

${ }^{16}$ Schacht miał również sceptyczne podejście do korzeni szariatu. Kwestionował wartość hadisów. Wskazywał raczej na ewolucyjny rozwój islamskiego prawa, które ukształtowało się w ciągu kilku pierwszych stuleci.

${ }^{17}$ Dutton wywodzi wszystkie szkoły prawne mahometańskie od Malika ibn Anasa al-Asbahiego (711-795). Autor uważa, że prawo islamskie powstało w ciągu pokolenia czy dwóch po śmierci ich Proroka. Podkreśla, że Malik nie opierał się na hadisach, a na czynach i praktyce islamskiej ( $\mathrm{amal}$ ) w Medynie. Tam wszyscy byli świadkami praktyki codziennej Mahometa. Zachowanie się tamtejszych mieszczan opierało się na przykładzie muzułmańskiego Proroka i w związku z tym było bardziej wiarygodne niż zapisy o jego rzekomych powiedzeniach z drugiej ręki. Dopiero gdy Malik - właściwie jako pierwszy - spisał tradycje na podstawie praktyki medyńskiej, stały się one podstawą islamskich szkół prawnych. Nawet ci twórcy szkół, którzy z nim się nie zgadzali, byli pełni podziwu dla solidności jego badań nad hadisami. Argument Duttona wzmacnia to, że faktycznie źródłami hadisów byli często najbliżsi towarzysze Mahometa. Większość z nich rozeszła się po światach islamu w ramach podboju. I każdy z nich miał inne wspomnienia na temat powiedzeń czy praktyki ich Proroka. W związku z tym każdy z nich przekazał w swoim zagranicznym środowisku inne tradycje (sunna). Natomiast pamięć o powiedzeniach i praktyce Mahometa zachowała się wśród właściwie wszystkich mieszkańców Medyny. Znali go i obserwowali. Każdy mógł skorygować
} 
komentarzy na temat rzekomych powiedzeń (hadith) Mahometa wyszła spod postmodernistycznego pióra Joela Blechera $(2018)^{18}$.

Wyjątkowo wybitną i pomocną ocenę logocentrycznych braków mahometanizmu zawarł w swej świetnej pracy konserwatysta katolicki, Robert R. Reily $(2010)^{19}$. W pewnym sensie analiza ta bardzo dobrze wpisuje się w kontekst filozoficznych przemyśleń o światach islamu, jaki sprezentował nam James V. Schall $(2007,2018)^{20}$. Na jeszcze bardziej wysublimowanym poziomie są przemyślenia Paula Stenhouse'a oraz - szczególnie - Samira Khalil Samira (Stenhouse, 2020) $^{21}$. Najbardziej surowe oceny o islamie zawarł w swojej pracy Luiz Sérgio Solimeo (2018). Ale analizy te muszą być zrównoważone wyśmienitą pochwałą intelektualnych osiągnięć rozmaitych geniuszy, głównie nie-Arabów, ale przede wszystkim muzułmanów - chociaż i chrześcijan, żydów,

opowieści o nim oraz zweryfikować większość z przekazów. Ponadto każdy naśladował Mahometa w taki sam sposób, jak czynili to sąsiedzi. Stąd Medyna rzeczywiście musi być uznana jako centrum pamięci i najbardziej autorytatywne zagłębie tradycji mahometańskiej w VII i VIII wieku (s. 36).

${ }^{18} \mathrm{Nie}$ można oprzeć się wrażeniu, że Blechera pociąga fakt relatywizmu islamu, przede wszystkim hadisów, co pozwala współczesnemu badaczowi odnosić się do teorii postmodernistycznych i dekonstrukcji, zwłaszcza ,dorobku” Michela Foucaulta. Zob. np. ciekawą dyskusję na temat tego, czy Mahomet był analfabetą, jak podkreśla Koran, czy też nie, jak sugerują niektóre interpretacje hadisów na przykładzie traktatu z Huadaibiyya z 628 roku (s. 21-29). Blechera zachwyca szczególnie hermeneutyczny „podwójny ruch” (double movement, s. 27), czyli zdecydowane potwierdzanie, że ich Prorok był niepiśmienny, z jednoczesnym podkreślaniem z całą stanowczością, że jednak potrafił pisać, co stwierdzał ten sam specjalista religijny - Abbu al-Ualid al-Badżi (1013-1081) z Andalusi. Al-Badżi zupełnie nie dostrzegał tej sprzeczności. Myśliciel ten żył w intelektualnym cieniu wybitnego teologa i prawnika z Kordoby, Ibn Hazm al-Andaluzi (994-1064), do którego głównie odnosi się Blecher. Więcej o tej personie zob. Adang, Fierro, Schmidtke (2012).

${ }^{19}$ Ambasador Reilly to mój znajomy i inspiracja intelektualna, szczególnie ze względu na jego dzielność. Nigdy nie unika tematów tzw. kontrowersyjnych. Polemicznie wobec tez Reilly’ego (uznanych fałszywie za „neokonserwatywne”) z punktu widzenia twardego katolickiego paleokonserwatyzmu zob. w: Jones (2016); w tym duchu debata wewnątrzislamska pod kątem etyki zob. Hourani (1985) oraz Arkoun (1984). O zwolennikach logos wśród mahometan zob. też Martin, Woodward i Atmaja (1997). Klasyczna tradycja (grecka i rzymska) stała się mimo wszystko integralną częścią wysiłku intelektualnego mahometan (zob. Rosenthal, 1965; O’Leary, 1949). Oczywiście w ramach kultury dworskiej zachowały się nawet w średniowieczu enklawy logiki (zob. Goodman, 2003). Odrzucenie logocentryzmu na poważne implikacje, m.in. dla muzułmańskiego podejścia do nauk ścisłych (zob. Hoodbhoy, 1991; Arkoun, 1984).

${ }^{20}$ Autor jest ewenementem: konserwatywny jezuita oraz emerytowany profesor Georgetown University.

${ }^{21}$ W przeciwieństwie do Reilly'ego i Schalla, Stenhouse zna arabski i inne narzecza lokalne. Niedawno zmarły Stenhouse był księdzem katolickim. Zob. Marek Jan Chodakiewicz, Fr. Paul Stenhouse, R.I.P., Crisis Magazine, January 21, 2020, https://www.crisismagazine.com/2020/fr-paul-sten house-r-i-p. Jeszcze lepszym ekspertem w tej dziedzinie jest ojciec Samir Khalil Samir, jezuita urodzony w Egipcie, z mieszanego arabsko-włoskiego małżeństwa, od długiego czasu zamieszkujący w Libanie (zob. Samir, 2008). 
taoistów, hinduistów i buddystów - dawnych wieków pod władzą islamu w Azji Środkowej. Ich autorem jest S. Frederic Starr (2015).

Wśród autorów studiów regionalnych nad cywilizacją islamu wyróżnia się przede wszystkim liberalny historyk oksfordzki, Albert Hourani, wywodzący się z libańskiej diaspory, który z prezbiterianizmu i prawosławia rodziców przeszedł na katolicyzm. W bardzo delikatny i wyważony sposób opisuje on dzieje swojej arabskiej grupy etnicznej, od czasu do czasu zatrąca niemal o apologetykę (Hourani, 1991). Jednak mistrzem popularyzatorstwa historii Arabów jest Phillip K. Hitti (1970; wyd. $1-1937^{22}$ ). Wspaniałe jest studium komparatystyczne muzułmańskich potęg nowożytności pióra Douglasa E. Streusanda (zob. Streusand, 2011) ${ }^{23}$. Wyczerpujące i monumentalne studium państwa Wielkiej Porty stworzyli Halil Inalcik i Donald Quataert $(1994)^{24}$. A życzliwą i popularnonaukową opowieść o dziejach Osmanów dał nam Lord Kinross (2002).

O szerzeniu się islamu w Afryce oraz rozmaitych innych aspektach zjawisk związanych z mahometanizmem dowiemy się m.in. z prac Nehemii Levtziona i Randalla Pouwelsa (Levtzion, Pouwels, 2000) ${ }^{25}$, Davida Robinsona oraz Romana Loimeiera. Robinson wprowadza nas do zagadnień muzułmańskich na Czarnym Kontynencie, w sposób przystępny dyskutując poszczególne krainy i objawy islamu (Robinson, 2004). Loimeier napisał dużo bardziej solidną i wnikliwą pracę na ten sam temat, wartą polecenia raczej dla zaawansowanych (Loimeier, 2013).

Z wybijających się pozycji o islamie Azji monografia Howarda M. Federspiela charakteryzuje się antropologicznym podejściem do zjawiska, opisywanego całościowo i syntetycznie na podstawie Indonezji, Filipin, Malezji i okolic

\footnotetext{
${ }^{22}$ Opublikowana po raz pierwszy przez Macmillan w roku 1937, praca ta doczekała się następnych wydań po roku 1970. Ostatnie pojawiło się bodaj w 1996 roku.

${ }^{23}$ Douglas jest wybitnym znawcą islamu, moim niedoścignionym kolegą z uczelni i źródłem wielu korekt i pomysłów, które wywarły poważny wpływ na moją pracę.

${ }^{24}$ Inalcik podkreśla, że monografia ta jest pisana „,z osmańskiego punktu widzenia” („,The volume attempts to present events from the Ottoman perspective. It offers the Ottomans as agents capable of independent and internally consistent actions and not, as had been the case for too long, as passive spectators of a European drama”, s. 3). Uważa, że praca jest korektą i dopełnieniem monumentalnej monografii Morza Śródziemnego autorstwa Fernanda Braudela (Braudel, 1972).

${ }^{25}$ Książka - wydana jednocześnie w Oksfordzie (wydawnictwo James Curry) oraz w Cape Town (wydawnictwo David Phillip) - opisuje wybrane zagadnienia z historii 1400 lat mahometanizmu w Afryce. Autorami jest 27 wiodących naukowców, stosujących rozmaite metodologie i koncentrujących się zarówno na poszczególnych regionach, jak i na wybranych aspektach cywilizacji islamskiej - od prawa do muzyki.
} 
(Federspiel, 2007). Podręcznikową próbę przedstawienia łagodnej wizji muzułmańskiego podboju i dominacji Indii podjął S. M. Ikram (1964).

O wchłonięciu muzułmańskich rejonów w Azji Środkowej przez Rosję oraz o stworzeniu państwowego systemu kolaboracji elity muzułmańskiej z carami traktuje Robert D. Crews (2006). Ciekawa jest też pozycja o muzułmanach jako gościach, a potem zasymilowanych tubylcach w krajach chrześcijańskich Międzymorza, czyli głównie o Tatarach Rzeczypospolitej, której autorem jest Harry Norris (2009) ${ }^{26}$.

Peter F. Sugar (1977) wychwala rzekome zyski dla chrześcijan z osmańskiej okupacji Bałkanów. Tymczasem o tragicznym losie podbitych przez mahometan niewiernych, szczególnie chrześcijan i żydów (dhimmi), głównie na Bliskim Wschodzie i w północnej Afryce, wnikliwie pisze w swoich pracach egipska sefardyjka, Bat Ye'or (to pseudonim urodzonej w Egipcie brytyjskiej autorki - Gisèle Littman; najważniejsze jej prace to: The Decline of Eastern Chrystianity, 1996, oraz Understanding Dhimmitude, 2013). Ich los był niewiele lepszy od niewolników. Żydzi i chrześcijanie cierpieli dyskryminację, byli poniżani i eksploatowani, głównie rękami swej własnej elity, która kolaborowała $\mathrm{z}$ muzułmańskimi prześladowcami sprawującymi nad wszystkimi absolutną władzę.

W tym kontekście warto zapoznać się z przemyśleniami o rasie i niewolnictwie w islamskim kontekście dwóch wybitnych naukowców: Bernarda Lewisa i Daniela Pipesa. Lewis pokazuje, że mahometanizm jest egalitarny i nie dyskryminuje w sensie rasowym. Jednak odurzeni sukcesem podboju muzułmańscy wojownicy Arabowie zaczęli się wywyższać rasowo i z pogardą traktować podbijanych niewolników, w tym także czarnych ${ }^{27}$. Pipes twierdzi natomiast, że w zderzeniu islamskiej teorii o pokoju między muzułmanami a praktyką wzajemnego wyrzynania się mahometan, arabscy wyznawcy Allaha porzucili rzemiosło wojenne i poczęli polegać na niewolnikach wojskowych tureckich z Azji Środkowej ${ }^{28}$.

\footnotetext{
${ }^{26}$ Niestety autor ma słabą wiedzę o I RP i Międzymorzu; por. Račius (2018).

${ }^{27}$ Lewis argumentuje, że początkowo Arabowie nie dostrzegali sensu wyższości rasowej; takowy stopniowo wyłonił się wśród nich wraz ze zwycięstwami islamu. „Bronzowi” ludzie mieli być najlepsi, a „różowi” (biali) pośledni, podczas gdy „czarny” kojarzył się jednoznacznie z niewolnikiem. Jednocześnie jednak - paradoksalnie - mahometanizm to religia egalitarna, która nie uznaje podziałów rasowych. Wiara ujarzmiała więc arabski szowinizm. Zob. Lewis $(1971,1990)$ oraz Hall (2011) i Marlow (1997). Apologetycznie o islamie w Afryce widzianej oczyma czarnego autora zob. Blyden (1888); por. z: Bennett (2019).

${ }^{28}$ Zob. Pipes (1981). Teza ta jest mocno dyskusyjna. Zwycięscy Arabowie w większości osiedlili się w miastach. Pasożytując na zdobyczach innych cywilizacji, nauczyli się wygody i porzucili chęć wojaczki, jak również przestali być do niej przystosowani jak ich koczowniczy przodkowie,
} 
Umiarkowany liberalny dziejopisarz, Hugh Kennedy, stara się opisywać raczej w wyważony sposób muzułmańską okupację Iberii („Andaluzji”29), chociaż krytycznie podchodzi głównie do strony chrześcijańskiej (Kennedy, 1996). Samobójczymi piewcami islamskiego jarzma w Hiszpanii i Portugalii - jako ziszczenia ideałów multikulturalizmu - są lewicowcy, Maria Rosa Menocal (2002) oraz Chris Lowney (2005). Antidotum na taką politycznie poprawną narrację jest wyśmienity katolicki konserwatysta, Darío Fernández-Morera (2016), który obnaża prześladowanie i martyrologię chrześcijan pod butem islamu. Bardziej wstrzemięźliwy w swych konkluzjach, choć podobnie realistyczny, jest Brian A. Catlos (2018), który podkreśla obecność zarówno konfliktu, jak i kooperacji między islamem i chrześcijaństwem w Andaluzji.

Ale chrześcijanie również przeciwstawiali się zalewowi mahometańskiemu, a nawet sięgali znów po swoje, co opisuje Joseph F. O'Callaghan (2003; zob. też O'Callaghan, 1975). Odbicie Iberii z rąk islamskich było jedyną zwycięską krucjatą, czego nie doceniamy, bowiem kontrofensywa chrześcijan zajęła dosłownie setki lat. Wśród wielu innych pozycji o krucjatach warto się zapoznać z książkami Henri Pirenne'a, Hilaire Belloca i Roberto De Mattei. Pirenne to wielki mediewista, który uznał, że to nie chrześcijaństwo, a islam zniszczył cywilizację antyczną, w tym także Rzymu, ze wszelkimi tego implikacjami ${ }^{30}$. Belloc to katolicki konserwatywny klasyk koncentrujący się przede wszystkim na geopolityce Pierwszej Krucjaty i powodach jej porażki (zob. Belloc, 1992). Współczesny konserwatywny katolik, De Mattei, zastanawia się nad moralnymi implikacjami dżihadu i krucjat, w których dżihad jest stałą normą, a krucjata - wyjątkiem, oraz odnosi je do czasów współczesnych (2007; zob. Kelsay, Johnson, 1991).

Jeśli chodzi o obecne potrzeby dotyczące zwalczania islamskiego terroryzmu, to dobrze naświetla ich korzenie David Fromkin. Pokazuje, że należy przemyśleć dyplomatyczne decyzje pokoju wersalskiego, które stworzyły w postosmańskim terytorium nowe realia geopolityczne, których głównym mankamentem jest chroniczny konflikt (Fromkin, 1989). Jak się przeciwstawiać wypełznięciu konfliktu poza światy islamu? J. Michael Waller robi krótki

o czym pisał już Ibn Khaldūn. Dziękuję Dougowi Streusandowi w utwierdzeniu mnie w moim sceptycyzmie co do interpretacji Pipesa. Zob. też Crone (1980).

${ }^{29}$ R. Burton twierdzi, że słowo to pochodzi od ,ziemia Wandali” (Vandal-land) - al-Aldalus. Zob. The Arabian Nights, s. 981 n. 23.

${ }^{30}$ Tzw. teza Pirenne'a jest naturalnie zaprzeczeniem i wyzwaniem dla teorii Lorda Gibbona o tym, że chrześcijaństwo rozwaliło Rzym. Według tego wielkiego mediewisty belgijskiego Islam zniszczył świat klasyczny, co umożliwiło pojawienie się na horyzoncie potęgi frankijskiej i innych germańskich tworów porzymskich (Pirenne, 1958; zob. też Havighurst, 1958). 
i przystępny wykład o twardej wojnie propagandowej, jaką należy prowadzić przeciw islamistycznym terrorystom (2007). Inni myśliciele podkreślają, że kalifatystów, islamistów i terrorystów można pokonać, opierając się na starych schematach zimnowojennych: ograniczaniu (containment), wojnie przez pośredników (wars by proxy), tajnych akcjach (covert operations) i kontrterroryzmie (counterterrorism) (zob. Gorka, Sookhdeo, 2012; Habeck, 2006; Gorka, 2016). Warto zwrócić tutaj uwagę chyba na najbardziej prominentego znawcę i krytyka tzw. islamu politycznego. Jest nim francuski naukowiec, Olivier Roy (1990, 2007, 2017).

Natomiast aby islamistom przeciwstawić się w Stanach Zjednoczonych i gdzie indziej na Zachodzie, należy poznać naturę tej cywilizacji oraz poinformować o niej współobywateli. Sam Solomon i E. Al-Maqdisi pokazują, jak tzw. migranci po prostu naśladują swego Proroka, który też emigrował, aby ustanowić państwo islamskie - bez wiedzy i często wbrew woli swoich gospodarzy (Solomon, Al-Maqdisi, 2009). Daniel Akbari i Paul Tetreault uczą, jak sprostać wyzwaniom patologii, jakie islamscy migranci przywlekli ze sobą, a które są esencją ich cywilizacji (Akbari, Tetreault, 2014). Istnieje też wiele popularnych wykładni antyapologetycznych. Ich zwolennicy widzą mahometanizm jednoznacznie jako zagrożenie dla niemuzułmanów ${ }^{31}$.

Dla złaknionych głębszej wiedzy jest też sporo wielojęzycznych - ze wskazaniem na preferencję angielskiego - periodyków poświęconych islamowi: jego historii, teologii, archeologii, literaturze, komparatystyce ${ }^{32}$. Większość $\mathrm{z}$ nich jest wysoce specjalizowana, na przykład The Journal of Islamic Manuscripts $^{33}$. Mamy też studia multidyscyplinarne, choćby wydawany przez Oxford University The Journal of Islamic Studies czy przez Indiana University The Journal of Islamic and Muslim Studies - oba z pozycji postępowych. Odwrotnie niż przygotowywany pod auspicjami neokonserwatywnego Hudson Institute Current Trends in Islamist Ideology ${ }^{34}$. Aby otrzeć się o świat kolorowych magazynów zajmujących się współczesnymi sprawami społeczności islamskiej na

\footnotetext{
${ }^{31}$ Część z grupy antyapologetycznej zachowuje standarty naukowe, a argumenty buduje w sposób realistyczny i wyważony. Inni nie bawią się w takie subtelności (por. Glazov, 2018; Faye, 2016; Coughlin, 2015; Murawiec, 2008; Davis, 2006, [b.r.], s. 1-44 oraz Bill Warner [William French] 2006, 2011 oraz jego prace z 2010 zamieszczone w Bibliografii w nieniejszym eseju).

${ }^{32}$ Zob. elektroniczną listę bibliograficzną periodyków: http://www.brill.com/files/brill.nl/index -islamicus-consulted-periodicals-yearbook-2010.pdf; http://guides.library.cornell.edu/c.php?g=1391 96\&p=3545394; https://middleeast.library.cornell.edu/content/academic-scholarly-journals; http://guid es.lib.umich.edu/islamicmsstudies/bibres.

${ }^{33} \mathrm{https}: / / \mathrm{www} \cdot$ brill.com/journal-islamic-manuscripts

${ }^{34} \mathrm{https} / / /$ www.hudson.org/policycenters/6-current-trends-in-islamist-ideology
} 
poziomie popularnym, należy zaprenumerować choćby Al-Hujjaj Magazine z RPA, poświęcony pielgrzymkom i wypełniony zdjęciami ${ }^{35}$.

Nie sposób w tym miejscu opisać wszystkie publikacje, ale z zaproponowanych tytułów każdy może znaleźć coś interesującego dla siebie - od wiernych do niewiernych, zarówno islamofilów, jak i islamofobów, i każdego pośrodku. Ukazałem tutaj zaledwie wierzchołek góry lodowej, jeśli chodzi o naukę dotyczącą światów islamu. Niech to będzie początkiem drogi dla zainteresowanych.

\section{BIBLIOGRAFIA}

Alatas Syed Farid (2013), Ibn Khaldun (Makers of Islamic Civilization), New Delhi: Oxford University Press.

Al-Baladhuri (1916), The Origins of the Islamic State (Kitab Futuh al-Buldan), thum. Philip K. Hitti, New York: Columbia University Press, https://archive.org/stream/KitbFutuhAlBuldanOrigi nalsOfTheIslamicStateEnglishTranslation 1916/Kitb+Futuh+Al+Buldan\%2C+Originals+Of+ The+Islamic+State+-+English+Translation+1916_djvu.txt

Adang Camilla, Fierro Maribel, Schmidtke Sabine (2012), Ibn Hazm of Cordoba: The Life and Works of a Controversial Thinker, Leiden: Brill Publishers.

Akbari Daniel, Tetreault Paul (2014), Honor Killing: A Professional's Guide to Sexual Relations and Ghayra Violence from the Islamic Sources, Bloomington, IN: AuthorHouse.

Alberuni's India: An Account of the Religion, Philosophy, Literature, Geography, Chronology, Astronomy, Customs, Laws and Astrology of India About A. D. 1030 (2002), tłum. i red. Edward C. Sachau, New Delhi: Rupa \& Co.

Ansary Tamim (2010), Destiny Disrupted: A History of the World Through Islamic Eyes, New York: Public Affairs.

Arkoun Mohammed (1984), Pour une critique de la raison islamique, Paris: Maisonneuve \& Larose.

Armstrong Karen (2002), Islam: A Short History, New York: The Modern Library.

Bat Ye'or (1996), The Decline of Eastern Christianity Under Islam: From Jihad to Dhimmitude: Seventh-Twentieth Century, Madison, NJ: Fairleigh Dickinson University Press.

Bat Ye'or (2013), Understanding Dhimmitude, New York: RVP Publishers.

Bell Gertrude (2015), A Woman in Arabia: The Writings of the Queen of the Desert, red. Georgina Howell, New York: Penguin.

Belloc Hilaire (1992), The Crusades: The World's Debate, Rockford, IL: Tan Books and Publishers, Inc.

Bennett Herman L. (2019), African Kings and Black Slaves: Sovereignty and Dispossession in the Early Modern Atlantic, Philadelphia, PA: University of Pennsylvania Press.

Berkey Jonathan P. (2002), The Formation of Islam: Religion and Society in the Near East, 600-1800, New York-Cambridge: Cambridge University Press, https://www.pdf-archive.com/2014/09/04/ berkey-the-formation-of-islam/

\footnotetext{
${ }^{35}$ Zob. https://home.mweb.co.za/ty/typeface/Hujjaj.html; inne propozycje w: https://www.tho ughtco.com/top-islamic-magazines-and-journals-2004262
} 
Bertram Thomas (1932), Arabia Felix: Across The Empty Quarter of Arabia, New York: Charles Scribner's Sons.

Blecher Joel (2018), Said the Prophet of God: Hadith Commentary Across a Millenium, Oakland, CA: University of California Press.

Blyden Edward W. (1888), Christianity, Islam, and the Negro Race, wyd. 2, London: W.B. Whittingham \& Co.

Braudel Fernand (1972), The Mediterranean and the Mediterranean World in the Age of Philip II, t. 1-2, tłum. Sian Reynolds, New York: Harper \& Row Publishers, Perennial Library.

Burton Sir Richard F. (1993), The Erotic Traveler, red. Edward Leigh, New York: Barnes \& Noble Books.

Burton Sir Richard F. (1964), Personal Narrative of a Pilgrimage to Al-Madinah \& Meccah, red. Isabel Burton, t. 1-2, New York: Dover Publications, Inc. [wyd. pamiątkowe - London: Tylston and Edwards, 1893]

Burton Richard (1856), First Footsteps in East Africa, Middletown, DE: Shepperd Publications. Print on demand 2015.

Catlos Brian A. (2018), Kingdom of Faith: A New History of Islamic Spain, New York: Basic Books.

Coughlin Stephen (2015), Catastrophic Failure: Blindfolding America in the Face of Jihad, Washington, DC: Center for Security Policy Press.

Crews Robert D. (2006), For Prophet and Tsar: Islam and Empire in Russia and Central Asia, Cambridge, MA-London: Harvard University Press.

Crone Patricia (1980), Slaves on Horses: The Evolution of the Islamic Polity, Cambridge, UK: Cambridge University Press.

Crone Patricia, Cook Michael (1977), Hagarism: The Making of the Islamic World, Cambridge-London-New York-Melbourne: Cambridge University Press, https://archive.org/stream/Hagarism/Ha garism\%3B\%20The\%20Making\%20of\%20the\%20Islamic\%20World-Crone,\%20Cook_djvu.txt.

Dale Stephen Frederic (2015), The Orange Trees of Marakesh: Ibn Khaldun and the Science of Man, Cambridge, MA-London: Harvard University Press.

Davis Gregory M. (2006), Religion of Peace?: Islam's War Against the World, Los Angeles, CA: World Ahead Publishing, Inc.

Davis Gregory M. [b.r.], Islam 101, https://www.jihadwatch.org/islam-101

Dunn Ross E. (1986), The Adventures of Ibn Battuta: A Muslim Traveler of the Fourteenth Century, Berkeley, CA: University of California Press.

Dutton Yasin (2002), The Origins of Islamic Law: The Qur'an, the Muwatta' and Madinan 'Amal, London: Routledge.

Encyclopedia Britannica (1910-1911), t. 1-29, red. Hugh Chisholm, Cambridge: Cambridge University Press.

Encyclopedia of the Qur'ān (2006), t. 6, red. Jane Dammen, McAuliffe, Brill Publishers.

Esposito John L. (red.) (1999), The Oxford History of Islam, Oxford-New York: Oxford University Press.

Esposito John L. (2011), Islam: The Straight Path, Oxford-New York: Oxford University Press.

Faye Guillaume (2016), Understanding Islam, tłum. Robert Adwan, London: Arktos.

Federspiel Howard M. (2007), Sultans, Shamans, and Saints: Islam and Muslims in Southeast Asia, Honolulu, HI: University of Hawai'i Press, https://archive.org/stream/SultansShamansAndSaintsOf IslamAndMuslimsInSoutheastAsiaByHowardM.Federspiel/Sultans, \%20Shamans\% 
Fernández-Morera Darío (2016), The Myth of the Andalusian Paradise: Muslims, Christians, and Jews under Islamic Rule in Medieval Spain, Willmington, DE: ISI Press.

Fromkin David (1989), A Peace to End All Peace: The Fall of the Ottoman Empire and the Creation of the Modern Middle East, New York: Henry Holt and Company.

Glazov Jamie (2018), Jihadist Psychopath: How He is Charming, Seducing, and Devouring Us, New York-Nashville, TN: Post Hill Press.

Goldziher Ignaz (1917), Mohammed and Islam, New Haven, CT-London-Oxford: Yale University Press, Humphrey Millford-Oxford University Press.

Goldziher Ignaz (1966), Muslim Studies (Muhammedanische Studien), t. 1-2, red. Samuel M. Stern, tłum. Renate C. Barber, Samuel M. Stern, London: Allen-Unwin.

Goldziher Ignaz (1981), Introduction to Islamic Theology and Law, tłum. Andras i Ruth Hamori, Princeton, NJ: Princeton University Press.

Goodman Lenn E. (2003), Islamic Humanism, Oxford: Oxford University Press.

Gorka Katherine C., Sookhdeo Patrick (red.) (2012), Fighting the Ideological War: Winning Strategies from Communism to Islamism, McLean, VA: Isaac Publishing-Westminster Institute.

Gorka Sebastian (2016), Defeating Jihad: The Winnable War, Washington, DC: Regnery Publishing.

Habeck Mary (2006), Knowing the Enemy: Jihadist Ideology and the War on Terror, New Haven-London: Yale University Press.

Hall Bruce S. (2011), A History of Race in Muslim West Africa, 1600-1960, New York: Cambridge University Press.

Hanne Olivier (2017), Les Seuils Du Moyen-Orient: Histoire des frontières et des territorires, Monaco: Éditions du Rocher.

Havighurst Alfred F. (red.) (1958), The Pirenne Thesis: Analysis, Criticism, and Revision, Boston, MA: D.C. Heath and Company.

Hitti Philip K. (1970), History of the Arabs, wyd. 10 [wyd. 1 - 1937], London: Palgrave Macmillan, https://archive.org/details/HistoryOfTheArabs-PhilipK.Hitti/page/n3

Hodgson Marshall G. S. (1977), The Venture of Islam (t. 1: The Classical Age of Islam; t. 2: The Expansion of Islam in the Middle Periods; t. 3: The Gunpowder Empires and Modern Times), Chicago, IL: University of Chicago Press.

Hoodbhoy Pervez (1991), Islam and Science: Religious Orthodoxy and the Battle for Rationality, London: Zed Books.

Hourani Albert (1991), A History of the Arab Peoples, New York: Warner Books.

Hourani George F. (1985), Reason and Tradition in Islamic Ethics, Cambridge: Cambridge University Press.

Ibn Battutah (2003), The Travels of Ibn Battutah, red. Tim Mackintosh-Smith, London: Picador.

Ibn Fadlān (2012), Ibn Fadlān and the Land of Darkness: Arab Travellers in the Far North, tłum. Paul Lunde, Caroline Stone, New York: Penguin Books.

Ibn Ishāa (1955), The Life of Muhammad: A Translation of Ibn Ishāaq's Sirat Rasul Allah, tłum. i red. Alfred Guillaume, Oxford: Oxford University Press.

Ibn Khaldūn (1958), The Muqaddimah: An Introduction to History, t. 1-3, thum. Franz Rosenthal, New York: Panthenon.

Ibn Khaldūn (1967), The Muqaddimah: An Introduction to History, tłum. Franz Rosenthal, skrót i red. N.J. Dawood, Princeton, NJ: Princeton University Press. 
Ibn Munqidh Usama (2008), The Book of Contemplation: Islam and the Crusades, thum. Paul M. Cobb, New York: Penguin Books.

Ikram S.M. (1964), Muslim Civilization in India, New York-London: Columbia University Press.

Inalcik Halil, Quataert Donald (red.) (1994), An Economic and Social History of the Ottoman Empire, 1300-1914, Cambridge: Cambridge University Press.

In the Lands of the Christians: Arabic Travel Writing in the Seventeenth Century (2003), thum. i red. Nabil Matar, New York-London: Routledge.

Irwin Robert (2018), Ibn Khaldun: An Intellectual Biography, Princeton, NJ-Oxford: Princeton University Press.

Jones E. Michael (2016), Islam and Logos, South Bend, IN: Fidelity Press.

Kelsay John, Johnson James T. (red.) (1991), Just War and Jihad: Historical and Theoretical Perspectives on War and Peace in Western and Islamic Traditions, New York: Greenwood Press.

Kennedy Hugh (1996), Muslim Spain and Portugal: Political History of Al-Andalus, LondonNew York: Routledge.

Kinross Lord (2002), The Ottoman Centuries: The Rise and Fall of the Turkish Empire, New York: Harper Perennial.

Lapidus Ira M. (2002), A History of Islamic Societies, wyd. 2, New York-Cambridge: Cambridge University Press.

Lawrence Thomas E. (1999), Seven Pillars of Wisdom, Ware, Hertfordshire: Wordsworth Editions Limited. [Wyd. pol.: Siedem filarów mądrości, t. 1-2, tłum. Jerzy Schwakopf, Warszawa: PIW 1971].

Levtzion Nehemia, Pouwels Randall L. (red.) (2000), The History of Islam in Africa, Athens, OH: Ohio University Press.

Lewis Bernard (1971), Race and Color in Islam, New York: Harper and Row.

Lewis Bernard (1990), Race and Slavery in the Middle East: An Historical Enquiry, Oxford-New York: Oxford University Press.

Loimeier Roman (2013), Muslim Societies in Africa: A Historical Anthropology, Bloomington, Indiana University Press.

Lowney Chris (2005), A Vanished World: Muslims, Christians, and Jews in Medieval Spain, Oxford-New York: Oxford University Press.

Marlow Louise (1997), Hierarchy and Egalitarianism in Islamic Thought, Cambridge: Cambridge University Press.

Martin Richard C., Woodward Mark R., Atmaja Dwi S. (1997), Defenders of Reason in Islam: Mu'tazilism from Medieval School to Modern Symbol, Oxford, England-Rockport, MA: Oneworld Publications.

Mattei De Roberto (2007), Holy War, Just War: Islam and Christendom at War, Rockford, IL: Chronicles Press-The Rockford Institute.

Menocal Maria Rosa (2002), The Ornament of the World: How Muslims, Jews, and Christians Created a Culture of Tolerance in Medieval Spain, Boston-New York: Little, Brown and Company.

Metcalf Barbara Daly (red.) (1984), Moral Conduct and Authority: The Place of Adab in South Asia Islam, Berkeley-Los Angeles: University of California Press.

Murawiec Laurent (2008), The Mind of Jihad, Cambridge: Cambridge University Press.

Naaman Erez (2016), Literature and the Islamic Court: Cultural life under al-Sahib Ibn 'Abbad, London: Routledge. 
Nakissa Aria (2019), The Anthropology of Islamic Law: Education, Ethics, and Legal Interpretation at Egypt's Al-Azhar, New York: Oxford University Press.

Nasr Seyyed Hossein (1978), An Introduction to Islamic Cosmological Doctrines: Conceptions of Nature and Methods Used for Its Study by the Ikhwān al-Safā', al-Bīrūnī, and Ibn Sīnā, London: Thames and Hudson.

Norris Harry (2009), Islam in the Baltics: Europe's Early Muslim Community, London-New York: I.B. Tauris Publishers.

O'Callaghan Joseph F. (1975), A History of Medieval Spain, Ithaca, NY: Cornell University Press.

O'Callaghan Joseph F. (2003), Reconquest and Crusade in Medieval Spain, Philadelphia, PA: University of Pennsylvania Press.

O'Leary De Lacy (19490, How Greek Science Passed to the Arabs, London: Routledge and Kegan Paul.

Pipes Daniel (1981), Slave Soldiers and Islam: The Genesis of a Military System, London-New Haven, CT: Yale University Press.

Pirenne Henri (1958), Mohammed and Charlemagne, New York: World Publishing Co.

Račius Egdūnas (2018), Muslims in Eastern Europe, Edinburgh: Edinburg University Press.

Robinson David (2004), Muslim Societies in African History, Cambridge-New York: Cambridge University Press.

Rosenthal Franz (1965), The Classical Heritage in Islam, tłum. Emile i Jenny Marmorstein, London-New York: Routledge.

Roy Olivier (1990), Islam and Resistance in Afghanistan, wyd. 2, Cambridge: Cambridge University Press.

Roy Olivier (2007), The New Central Asia: Geopolitics and the Birth of Nations, New York, NY: New York University Press.

Roy Olivier (2017), In Search of the Lost Orient: An Interview [wywiad z Olivierem Royem przeprowadzony przez Jean-Louis Schlegela], tłum. C. Jon Delogu, New York: Columbia University Press.

Reilly Robert R. (2010), The Closing of the Muslim Mind: How Intellectual Suicide Created the Modern Islamist Crisis, Wilmington, DE: ISI Books.

Samir Kalil Samir, S.J. (2008), 111 Questions on Islam: Samir Kalil Samir, S.J. on Islam and the West: A Series of Interviews Conducted by Giorgio Paolucci and Camille Eid, red. i thum. Wafik Nasry, SJ, Claudia Castellani, San Francisco, CA: Ignatius Press. [Wyd. pol.: Islam. Sto pytań, tłum. Karol Klauza, Warszawa: Instytut Wydawniczy PAX, 2004].

Schacht Joseph (1966), Origins of Muhammadan Jurisprudence, Oxford: Clarendon Press.

Schacht Joseph (1983), An Introduction to Islamic Law, New York-Oxford: Clarendon Press-Oxford University Press.

Schall James V. (2007), The Regensburg Lecture, South Bend, IN: St. Augustine's Press.

Schall James V. (2018), On Islam: A Chronological Record, 2002-2018, San Francisco, CA: Ignatius Press.

Shihab Al-Din Al-Nuwayri (2016), The Ultimate Ambition in the Arts of Erudition: A Compendium of Knowledge from the Classical Islamic World, New York: Penguin Books.

Šihāb ad-Dīn Aḥmad bin Àbd al-Qāder bin Sālem bin Ùtmān ['Arab Faqih], The Conquest of Abyssinia: 16th Century, tłum. Paul Lester Stenhouse, przypisy Richard Pankhurst, Hollywood, CA: Tsehai Publishers. 
Solimeo Luiz Sérgio (2018), Islam and the Suicide of the West: The Origin, Doctrine, and Goals of Islam, Spring Grove, PA: The American Society for the Defense of Tradition, Family and Property - TFP.

Solomon Sam, Al-Maqdisi Elias (2009), Modern Day Trojan Horse: Al-Hijra, the Islamic Doctrine of Immigration: Accepting Freedom or Imposing Islam?, Charlottesville, VA: ANM Publishers.

Starr S. Frederic (2015), Lost Enlightenment: Central Asia's Golden Age from the Arab Conquest to Tamerlane, Princeton, NJ: Princeton University Press.

Stenhouse Paul (2020), Islam: Context and Complexity, North Melbourne, Victoria: Australian Scholarly Publishing.

Streusand Douglas E. (2011), Islamic Gunpowder Empires: Ottomans, Safavids, and Mughals, Boulder, CO: Westview Press.

Sugar Peter F. (1977), Southeastern Europe under Ottoman Rule, 1354-1804, Seattle, WA-London: University of Washington Press.

The Arabian Nights: Tales from a Thousand and One Nights (2004), tłum. Richard F. Burton, New York: The Modern Library.

The Cambridge History of Islam (1970), t. 1-2, red. P.M. Holt, Ann K.S. Lambton, Bernard Lewis, Cambridge: Cambridge University Press.

The New Cambridge History of Islam (2010), t. 1-6, red. naczelny Michael Cook, Cambridge-New York: Cambridge University Press.

The Koran (1997), tłum. N.J. Dawood, London-New York: Penguin Books.

Trifkovic Serge (2002), The Sword of the Prophet: Islam. History, Theology, Impact on the World, Boston, MA: Regina Orthodox Press.

Waller, J. Michael (2007), Fighting the War of Ideas Like a Real War, Washington, DC: The Institute of World Politics Press.

Warner Bill (red.) (2006), A Simple Koran: Reconstructed Historical Koran: The Islamic Trilogy, t. 1-3, [b.m.]: CSPI.

Warner Bill (2010), A Two-Hour Koran (A Taste of Islam), [b.m.]: CSPI.

Warner Bill (2010), The Life of Mohammed: The Sira (A Taste of Islam), [b.m.]: CSPI.

Warner Bill (2010), The Hadith: The Sunna of Mohammed (A Taste of Islam), [b.m.]: CSPI.

Warner Bill (2010), Sharia Law for Non-Muslims (A Taste of Islam), [b.m.]: CSPI.

Warner Bill (2010), The Islamic Doctrine of Women (A Taste of Islam), [b.m.]: CSPI.

Warner Bill (2010), The Doctrine of Slavery (A Taste of Islam), [b.m.]: CSPI.

Warner Bill (2010), The Islamic Doctrine of Christians and Jews (A Taste of Islam), [b.m.]: CSPI.

Warner Bill (2011), A Self-Study Course on Political Islam, t. 1 (A Taste of Islam), [b.m.]: CSPI.

Wilfred Thesiger (2008), The Marsh Arabs, New York: Penguin Books.

Wilfred Thesiger (2012), Arabian Sands, New York: Penguin Books.

William of Tyre (1943), A History of Deeds Done Beyond the Sea, tłum. Emily A. Babcock, August Ch. Krey, New York: Columbia University Press. 